\title{
Motives of Foreign Firms in Pakistan
}

\author{
Mohammad H. Akhtar and Peter J. Buckley ${ }^{1}$
}

\begin{abstract}
:
To date no study has been made to explore the FDI motives of foreign firms in Pakistan. An attempt has been made to rectify this position through a survey of both wholly- and majority-owned multinational enterprises (MNEs) in the economy. Market size and growth variables appear to be the most cited reasons for FDI by MNEs in the sample. The use of exploratory factor analysis (EFA) also reinforces the significance of market size as the motive for FDI in Pakistan. The other underlying factors produced by the EFA are: expansion of business, low input prices, desire to lower the transaction costs and psychic distance.
\end{abstract}

\section{Introduction}

Whilst Foreign Direct Investment (FDI) has been discussed extensively, there seems to be no evidence of any research exclusively undertaken on the motives of foreign firms in Pakistan. Overseas investment, being significantly lower in Pakistan as compared to the economies of East Asia, has escalated in recent years. This reflects both the trends of foreign investors towards the economy and increasing commitment on the part of the government. Pakistan is adopting liberal policies to attract more and more FDI in the economy by making the policy environment more favourable towards foreign investors. The purpose of this study is to examine the determining and deterring forces that lie behind such trends in Pakistan. A survey of wholly and majority-owned subsidiaries/branches of MNEs was conducted to know about their motives for FDI in Pakistan.

The remaining part of the study is organised as under: Part 2 investigates the literature on FDI motivations of MNEs. Part 3 sets forth the details of sample selection, its features and research methodology. Detailed findings of the survey, on the motives for FDI in Pakistan are set out in part 4. Conclusions are arrived at in the final part.

\footnotetext{
1 The authors are respectively Assistant Professor of International Business and Economics, Department of Commerce, B. Z. University, Multan, Pakistan and Director, Centre for International Business, University of Leeds (CIBUL), Leeds University Business School, United Kingdom.
} 


\section{Empirical Investigation}

A sizable amount of literature exists in the form of surveys and case studies to explore the factors behind FDI activity. This has been of immense value in understanding the FDI motivations of MNEs. It reveals the reasons behind policy choices for investment abroad and manifests that FDI can be activated by the ownership, location and internalisation (OLI) factors.

Ownership-specific advantages are the factors that provide some competitive edge to a firm or group of firms over the others and result from the conditions of imperfect markets. These advantages accrue to an enterprise because of the possession of intangible assets such as trademarks, patents, production management, organisation and marketing system, and research and development (R\&D) capacity, etc. Such advantages are not easy to disseminate for the alleged intention of possessing firms to take maximum advantage from them. So these remain exclusive and specific to firms, at least in the short run. Such factors play a great role in motivating FDI as these could be best exploited through it rather than the other forms of servicing markets e.g. exports or licensing. Empirical support for such factors comes through the works of Wilkins $(1970,1974)$; Nicholas (1982); Wells (1983); Chen (1983) and Kumar and Kim (1984).

Location factors are believed to be the attributes of a location that make it more attractive and receptive to direct foreign investment. These include possession of certain natural resources, better marketing prospects, availability of cheap labour, lower production costs, better investment climate, political stability, and proximity to large potential markets, etc.. These are the L-factors of the 'pull' variety. Sometimes home market considerations such as supportive policies of the government, political risks, higher labour costs, shortage of labour, appreciation of currency etc. compel the MNEs to serve foreign markets through FDI. These are again the Lfactors but of the 'push' type. The issue of identifying and evaluating factors which influence firms in the location of their FDI is addressed by Brash (1966); Reuber et al. (1973); Franko (1976); Lecraw (1977); Ajami and Ricks (1981); World Bank (1989); Hasan and Nishat (1989); Bürgenmeier (1991) and Hood and Taggart (1997).

Internalisation factors reflect the costs incurred and benefits not received under the market mechanism. Costs are the transaction costs incurred during the process of exchange in the international market via exporting, licensing or contracting. Such costs take the form of uncertainties in finding suppliers, costs in making and monitoring contracts, maintaining product quality, government interventions such as tariffs, 
quotas, price controls, tax differences and so on. Benefits include economies of scope and specialisation, horizontal and vertical integration, lower transaction costs, controlling market outlets and enjoying protected use of firm-specific factors etc. Such imperfections in markets motivate firms to undertake certain activities and transactions within their organisation (internalisation) rather than carrying on through the market mechanism. Internalisation factors make it less costly to allocate international resources internally. The contribution of such factors in motivating direct investment is reflected by the studies of Buckley and Mathew (1979); Nicholas (1982); Shepherd et al. (1985) and Artisien et al. (1991).

The existing literature provides the basis for present research aimed at developing an insight into FDI motives of MNEs in Pakistan. The focus is on the following aspects:

- To explore the relative significance of OLI factors for MNEs' investment in Pakistan in general, across their nationality and pattern of ownership.

- To develop a parsimonious set of factors that lead to FDI, through the use of factor analysis.

\section{Sample and Research Methodology}

\subsection{Sample Selection}

As it was difficult to survey the whole population of the affiliates of MNEs in Pakistan on account of time and resource constraints, the task was accomplished through a selected sample of the MNEs. The sample was expected to reflect the following broad characteristics:

- To provide varied industrial coverage.

- Represent MNEs across different source countries.

- Consisting of MNEs with a share of either more than 51 per cent or 100 per cent by the parent. The reasoning for such a selection was based on extracting true information from foreign investors who are the main decision makers in the investment process.

- To gain some insight into the FDI motives of MNEs in Pakistan in order to form the basis for future research.

The target population of the MNEs was determined through the Government of Pakistan (GOP) (1993). Information was obtained through 
Dun \& Bradstreet (1996) concerning the share pattern and nationality of the MNEs in Pakistan. An initial sample of 69 of the total population of 214 companies was compiled from the GOP (1993) with the list of multinationals and companies with foreign equity in Pakistan. The majority of the MNEs in the initial sample consisted of manufacturing MNEs mostly from the UK and USA. As the primary aim of the study was to collect information from various firms across different sectors and nationalities, this led to the selection of a sample originating from the various host countries across manufacturing, trading and service sectors. Hence, a list of 43 MNEs was finalised considering that these MNEs possessed the necessary features (mentioned above) to determine a potentially useful sample for the survey. Selection of the sample can be best described as purposive sampling based on the judgement design. The use of such a mode of sample selection was intended to include firms from major industry groups and with a greater knowledge of the market through their longer presence in Pakistan. On the basis of available knowledge, concerning the population of MNEs in Pakistan and the nature of research objectives, such a mode of sample selection appeared to be efficient. The sample was considered to be useful in the following domains. Firstly, to provide an understanding of traits and dynamics of the various subsidiaries of MNEs. Secondly, to gain an insight into their motives for FDI in Pakistan. Thirdly, in drawing some broad conclusions and appropriate policy formulations for attracting larger inflows of FDI into Pakistan.

Table-1: Classification of the MNEs, across sectors and nationality, actually surveyed

\begin{tabular}{lcccccc}
\hline \multicolumn{1}{c}{ Sectors } & \multicolumn{6}{c}{ Countries } \\
\hline & UK & USA & Japan & Germany & Others* & Total \\
\hline Manufacturing & 2 & 2 & 0 & 5 & 3 & 12 \\
Service & 2 & 3 & 1 & 1 & 6 & 13 \\
Trading & 2 & 0 & 3 & 0 & 2 & 7 \\
\multicolumn{1}{c}{ Total } & $\mathbf{6}$ & $\mathbf{5}$ & $\mathbf{4}$ & $\mathbf{6}$ & $\mathbf{1 1}$ & $\mathbf{3 2}$ \\
\hline
\end{tabular}

* Include MNEs from UAE (3), Korea (2), Netherlands (2), Australia \& New Zealand (1), France (1), Switzerland (1) and Miscellaneous (1). 
Table-2: Classification of assets, sales/revenue and exports of the MNEs (No. of firms)

\begin{tabular}{lccc}
\hline Value (million Rs) & Assets & Sales/Revenue & Exports \\
\hline Upto 50 million & 4 & 1 & 3 \\
51 to 100 million & 3 & - & - \\
101 to 300 million & 6 & 2 & - \\
More than 300 million & 2 & 11 & - \\
Not applicable & - & - & 24 \\
\hline
\end{tabular}

\subsection{Features of the Sample Surveyed}

The sample comprises the subsidiaries/branches of the MNEs in manufacturing, service and trading sectors in Pakistan. Manufacturing firms were the firms mainly involved in the production of electrical goods and appliances (3), consumer care, pharmaceutical and chemical products (6), pumps and valves (1), oil extraction (1) and the generation of electricity (1). Service companies consisted mainly of banks (10), insurance (2) and shipping companies (1). Trading companies were mainly involved in export and import merchanting (5), supplying computers and office appliances etc. (2). The responding firms are classified in Table-1 according to their nationality and industry groups. Classification of assets, sales/revenue and exports of the MNEs surveyed is also indicated in Table $-2^{2}$.

\subsection{Data Collection}

Data for the survey was collected through detailed interviews with the subsidiaries/branches of the MNEs in Pakistan, based on a structured and pre-tested questionnaire ${ }^{3}$. It was considered that data collected through detailed discussions and interviews would be more comprehensive, accurate and dependable as compared to a mailed survey. Non-response by some of the MNEs, either on account of policy matters or due to their prior commitments, resulted in our dependence on the MNEs willing to participate in the survey.

Of the 43 MNEs contacted for an interview in Pakistan, 30 responded to the request. Among the rest, 9 companies declined to take

\footnotetext{
${ }^{2}$ The information is incomplete as some of the firms were reluctant to provide data on these fronts.

${ }^{3}$ The questionnaire is available with the author on request.
} 
part as it was against their policy to participate in any survey. For the rest of the 4 MNEs, questionnaires were left with them as it was difficult for them to manage time for an interview due to their prior commitments. After various reminders to these firms, two of them responded by sending back the questionnaires left with them, making a total of 32 respondent firms ${ }^{4}$.

\section{Results of the Study}

Detailed findings of the survey on FDI motives of MNEs in Pakistan are presented below. The results of the survey need to be viewed with caution because of the following reasons: 1)- limitations of the nonprobability sampling technique, mainly in terms of generalisability of the results; 2)- a selection bias that might have resulted from the purposive sampling technique used in selecting the sample. 3)- an interview bias resulting from the on-site visits, and finally; 4)- an eventual bias produced by non-response of some of the MNEs, affecting the overall response in a more positive or negative direction.

\subsection{FDI motives of the MNEs in Pakistan}

This part of the paper highlights the issue of why MNEs undertake direct investment in Pakistan. The managers interviewed were not the same as those who made the initial decision to invest in Pakistan. Hence, at the time of the interview, the firms were asked to rate the factors that might have been important in the investment decisions of their parents. Each of the factors was rated on a scale of 1 to $5^{5}$ where 1 represented the most important and 5 stood for insignificant. The average importance of each of the motives, perceived for FDI in Pakistan, is presented in Table-3 below indicating the sample and sectoral ratings.

Although the degree of strength of each of the motives for FDI varies across sectors, these are not mutually exclusive within each sector as manifested by their average scores. Caution has to be taken while interpreting these results for two reasons. Firstly, the managers interviewed were not the original decision makers and secondly, their opinion is based upon subjective judgement of the factors that might have led the MNEs to invest in Pakistan.

\footnotetext{
${ }^{4}$ A list of the MNEs surveyed can be obtained from the author.

${ }^{5}$ Where 1= Very important, 2= Important, 3= Adequate, 4= Indifferent and 5= Irrelevant
} 
Table-3: Average importance of the motives for FDI in Pakistan: Sample and sectoral averages

\begin{tabular}{|c|c|c|c|c|c|}
\hline Rank & Motives & $\begin{array}{c}\text { Sample } \\
\text { Means }\end{array}$ & Mfg. & Service & Trading \\
\hline 1 & Market size & 1.38 & 1.25 & 1.38 & 1.57 \\
\hline 2 & Market growth prospects & 2.03 & 2.33 & 1.85 & 1.86 \\
\hline 3 & Higher rates of profits & 3.06 & 3.17 & 2.62 & 3.71 \\
\hline 4 & Parent's strategy & 3.19 & 3.50 & 2.85 & 3.29 \\
\hline 5 & Lack of competition & 3.94 & 3.67 & 3.92 & 4.43 \\
\hline 6 & Access to neighbouring markets & 4.09 & 3.67 & 4.77 & 3.57 \\
\hline 7 & Historical links & 4.13 & 4.50 & 3.77 & 4.14 \\
\hline 8 & Low labour costs & 4.22 & 2.92 & 5.00 & 5.00 \\
\hline 9 & To overcome tariff barriers & 4.37 & 3.58 & 5.00 & 4.57 \\
\hline 10 & Product diversification & 4.47 & 4.00 & 4.62 & 5.00 \\
\hline 11 & Low production costs & 4.53 & 3.75 & 5.00 & 5.00 \\
\hline 12 & Surplus labour & 4.56 & 3.83 & 5.00 & 5.00 \\
\hline 13 & Low transport costs & 4.59 & 3.92 & 5.00 & 5.00 \\
\hline 14 & To overcome non-tariff barriers & 4.66 & 4.08 & 5.00 & 5.00 \\
\hline 14 & Cultural links & 4.66 & 5.00 & 4.15 & 5.00 \\
\hline 14 & Protection of existing export market & 4.66 & 4.83 & 5.00 & 3.71 \\
\hline 15 & Lower costs of establishing projects & 4.69 & 4.17 & 5.00 & 5.00 \\
\hline 15 & Geographical proximity & 4.69 & 5.00 & 4.23 & 5.00 \\
\hline 16 & Special economic zones & 4.75 & 4.33 & 5.00 & 5.00 \\
\hline 17 & Competitor's reaction & 4.78 & 4.83 & 4.62 & 5.00 \\
\hline 18 & Special privileges by the government & 4.87 & 4.67 & 5.00 & 5.00 \\
\hline 18 & Availability of raw materials & 4.87 & 4.67 & 5.00 & 5.00 \\
\hline$* 19$ & Ethnic ties & 5.00 & 5.00 & 5.00 & 5.00 \\
\hline$* 19$ & Problems in licensing arrangements & 5.00 & 5.00 & 5.00 & 5.00 \\
\hline$* 19$ & Problems with existing agency & 5.00 & 5.00 & 5.00 & 5.00 \\
\hline$* 19$ & Lack of unionisation of labour & 5.00 & 5.00 & 5.00 & 5.00 \\
\hline
\end{tabular}

Notes: Mfg.= Manufacturing sector

* None of the firms in the sample found these factors as relevant.

\subsubsection{Market size and Growth prospects}

The definition of market size needs to be perceived in the context of the nature of business carried out by MNEs in the sample. For the manufacturing MNEs, market size represents all the segments of the 
population in Pakistan. But the notion of market size seems to be more restricted for non-manufacturing MNEs where it comprises mainly the upper class consumers and business community of the economy. Market size appeared as the most important factor for investing in Pakistan followed by market growth prospects. These factors had a strong pull for the firms in the sample across nationality, sectors, time of entry and ownership patterns. These findings are in agreement with the literature on market size and growth variables (Brash 1966, Wilkins 1970, Franko 1976, Reuber et al. 1973, Ajami and Ricks 1981, World Bank 1989, Artisien et al. 1991, Bürgenmeier 1991, Hood and Taggart 1997).

Table-4: Average importance of the motives for FDI in Pakistan: by nationality

\begin{tabular}{|c|c|c|c|c|c|}
\hline Motives & UK & USA & Japan & Germany & Others \\
\hline Market size & 1.17 & 1.20 & 1.25 & 1.33 & 1.64 \\
\hline Market growth prospects & 2.00 & 2.60 & 2.00 & 1.83 & 1.91 \\
\hline Higher rates of profits & 3.00 & 3.40 & 3.75 & 3.67 & 2.36 \\
\hline Parent's strategy & 3.67 & 4.40 & 3.75 & 2.50 & 2.55 \\
\hline Lack of competition & 4.00 & 3.20 & 4.00 & 3.50 & 4.45 \\
\hline Access to neighbouring markets & 4.17 & 4.00 & 3.50 & 3.83 & 4.45 \\
\hline Historical links & 2.00 & 5.00 & 5.00 & 5.00 & 4.09 \\
\hline Low labour costs & 4.33 & 3.80 & 5.00 & 3.50 & 4.45 \\
\hline To overcome tariff barriers & 4.50 & 4.40 & 5.00 & 5.00 & 3.73 \\
\hline Product diversification & 4.50 & 4.20 & 5.00 & 4.67 & 4.27 \\
\hline Low production costs & 4.17 & 4.20 & 5.00 & 4.33 & 4.82 \\
\hline Cultural links & 5.00 & 5.00 & 5.00 & 5.00 & 4.00 \\
\hline Geographical proximity & 5.00 & 5.00 & 5.00 & 5.00 & 4.09 \\
\hline Surplus labour & 4.50 & 4.80 & 5.00 & 4.33 & 4.45 \\
\hline Low transport costs & 4.50 & 5.00 & 5.00 & 4.33 & 4.45 \\
\hline Protection of existing export market & 4.17 & 5.00 & 4.25 & 5.00 & 4.73 \\
\hline Special economic zones & 5.00 & 4.40 & 5.00 & 4.17 & 5.00 \\
\hline Lower costs of establishing projects & 4.50 & 4.60 & 5.00 & 4.67 & 4.73 \\
\hline Competitor's reaction & 5.00 & 5.00 & 5.00 & 5.00 & 4.36 \\
\hline To overcome non-tariff barriers & 4.67 & 4.80 & 5.00 & 4.50 & 4.55 \\
\hline Availability of raw materials & 5.00 & 4.20 & 5.00 & 5.00 & 5.00 \\
\hline Special privileges by the government & 5.00 & 5.00 & 5.00 & 5.00 & 4.64 \\
\hline Ethnic ties & 5.00 & 5.00 & 5.00 & 5.00 & 5.00 \\
\hline Problems in licensing arrangements & 5.00 & 5.00 & 5.00 & 5.00 & 5.00 \\
\hline Problems with existing agency & 5.00 & 5.00 & 5.00 & 5.00 & 5.00 \\
\hline Lack of unionisation of labour & 5.00 & 5.00 & 5.00 & 5.00 & 5.00 \\
\hline
\end{tabular}


There were significant differences among firms in the sample across their motives to invest in Pakistan in terms of their size. For instance, MNEs having smaller size subsidiaries or branches with assets of 50 to 100 million rupees were found to be more motivated by market growth prospects followed by market size. For the MNEs with assets of 51 to 300 million rupees, market size appeared as more important rather than market growth. The significance of these motives is further strengthened by the fact that the manufacturing firms in the sample were mainly in Pakistan to serve the local market as revealed by the survey results. The results indicate that there is strong evidence to support the notion of market-seeking FDI as market size appeared to be very important to 63 per cent of the firms in the sample.

Table-5: Average importance of motives: By ownership pattern

\begin{tabular}{lcc}
\hline \multicolumn{1}{c}{ Motives } & $\mathbf{1 0 0 \%}$ & $\mathbf{5 1 - 9 9 \%}$ \\
\hline Market size & 1.43 & 1.27 \\
Market growth prospects & 1.95 & 2.18 \\
Higher rates of profits & 2.95 & 3.27 \\
Parent's strategy & 3.14 & 3.27 \\
Lack of competition & 4.00 & 3.82 \\
Historical links & 4.10 & 4.18 \\
Access to neighbouring markets & 4.38 & 3.55 \\
Protection of existing export market & 4.57 & 4.82 \\
Cultural links & 4.62 & 4.73 \\
Geographical proximity & 4.67 & 4.73 \\
Product diversification & 4.67 & 4.09 \\
Availability of raw materials & 4.81 & 5.00 \\
To overcome tariff barriers & 4.86 & 3.45 \\
Low labour costs & 4.86 & 3.00 \\
Low production costs & 4.86 & 3.91 \\
Competitor's reaction & 4.90 & 4.55 \\
To overcome non-tariff barriers & 5.00 & 4.00 \\
Lower costs of establishing projects & 5.00 & 4.09 \\
Ethnic ties & 5.00 & 5.00 \\
Special economic zones & 5.00 & 4.27 \\
Problems in licensing arrangements & 5.00 & 5.00 \\
Problems with existing agency & 5.00 & 5.00 \\
Lack of unionisation of labour & 5.00 & 5.00 \\
Special privileges by the government & 5.00 & 4.64 \\
Surplus labour & 5.00 & 3.73 \\
Low transport costs & 5.00 & 3.82 \\
\hline
\end{tabular}




\subsubsection{High rates of profits}

Higher rates of profits was the next important motive for FDI in Pakistan after market size and growth factors. This motive was rated as adequately important both by the service and manufacturing MNEs. However, the service MNEs appeared to be more motivated by offensive i.e. profit-seeking reasons for FDI. Profit motive was also rated as important by firms with larger sales/revenues and fixed assets in Pakistan. The motive was found to be adequately important by the firms from the United States, group of others and those with the wholly-owned investment profile.

\subsubsection{Parent's strategy}

For some of the firms (14.44 per cent), direct investment in Pakistan took place as an integral part of the overall strategy of the parents towards globalised production and sales. The parent's strategy represents actions of the parent firms taken on the basis of certain perceived advantages, being explicit or implicit to them, of investing in Pakistan. The parent's strategy emerged as adequately important for the service and trading firms. The MNEs investing in Pakistan after 1948 and onward found this factor to be adequately important than those entering before this period of time. This motive also captured an important place for the MNEs with small size subsidiaries and also those exporting from Pakistan. MNEs from Germany and group of others were found to be more motivated by this factor than their counterparts from Japan, UK and USA.

\subsubsection{Other motives}

The market-seeking characteristic of all of the MNEs in the sample is also complemented by other features as well. For instance, MNEs in the manufacturing sector were more motivated by low labour costs in Pakistan than higher rates of profits. The geographical location of Pakistan was also seen as advantageous by some of the trading firms where access to neighbouring markets was deemed to be adequately important for FDI in Pakistan and for the service MNEs, higher rates of profits were found to be an adequate reason to invest. This reflects the fact that manufacturing MNEs are low cost-seeking unlike the service firms which are found to be profit-seeking. Special privileges by the government also turned out to be significantly important for one of the firms in the manufacturing sector. Such privileges mainly took the form of complete security against investment, exchange rate guarantee and zero tariff on production. The motive to overcome tariff barriers appeared to be very important for larger firms and the firms exporting from Pakistan. There appeared to be a marked difference, across motives for FDI in Pakistan, among three of the MNEs from Muslim countries in the 
sample and those from the rest of the world. The results of crosstabs indicated the fact that the Muslim countries' MNEs were predominantly motivated by cultural links and factors such as market size, geographical proximity and parent strategy, being of the same significance, were next. In addition to that, these were the MNEs found to be motivated by psychic distance factors e.g. cultural bias, geographical proximity and historical links only. In the context of the historical links, there was also great evidence from the British MNEs investing in Pakistan on account of colonial bias.

It is evident from the analyses of Tables 3 to 5 that the most important motives, in actual practice, for FDI in Pakistan are primarily concerned with the market-seeking activity. The overwhelming significance of the factors related with the market-seeking nature of FDI in Pakistan is that of highlighting the existence of market potential in the economy. There seems to be limited evidence for the existence of potential for efficiencyseeking FDI in Pakistan as only 3 of the manufacturing MNEs were found to be exporting from Pakistan. This might be due to the protectionist policies followed by Pakistan for a long time and the existence of an anti-export bias in the trade regime resulting from such policies. However, this result needs to be viewed with caution on account of non-response by some of the MNEs. By the same token, low labour costs appeared to be important for manufacturing MNEs in Pakistan, the motive is not complemented by higher degree of significance of the motive for access to neighbouring markets. This might be an indication of the fact that the MNEs are trying to maintain/improve their competitiveness while serving the local market. Therefore, from the survey findings, it would be difficult to establish the existence of export-oriented motive for FDI in Pakistan.

\subsubsection{Factor analysis on the motives of FDI in Pakistan}

FDI motives are seen to be varying across sectors, nationality and ownership thus, an exploratory factor analysis ${ }^{6}$ (EFA) was also conducted to detect the underlying factors in each category of motives for FDI in

\footnotetext{
${ }^{6}$ Factor analysis is a statistical technique to represent a large number of variables into a few underlying factors. The variables, on the basis of their interrelationships, are grouped into few factors reflecting the fact that there exist some patterns in relationship among the variables. Each factor, comprising different variables is an explanation of each of the variables in that factor. Variables having a greater association with each factor appear with a high factor loading or correlation indicating the respective factor's score. Eigenvalues of greater than 1 are used as a criterion to select factors explaining the greater amount of variance in the data. Factor analysis is exploratory when it is used to find out if there exists any structure among a set of variables to present the data in a reduced form. In such a situation, the resulting factors are not known in advance and there are no constraints to be met, on a priori basis, by the analysis.
} 
Pakistan. This is also considered useful for the reason that some of the motives ranked highly important by some of the MNEs appeared as insignificant in the overall sample. To achieve greater reliability in the analysis and for meaningful results, literature on factor analysis suggests a larger sample size than the variables to be examined in factor analysis. There is, however, no limitation on applying the factor analysis technique as long as the number of subjects is greater than the number of variates (Kline, 1994, p. 74 and Bryman and Cramer, 1997, p. 279).

The EFA was based on principal component extraction and in order to eliminate any chances of correlation among factors, varimax rotation method was employed. This initially resulted in 9 factors explaining 84 per cent of the overall variance. Table-6 shows the factors extracted with appropriate labels assigned to them on the basis of items within each factor. An examination of factor-item loadings and variances accounted for by the individual factors reveals that the uncovered structure of factors adequately captures the information contained in the variables.

\section{Lowering the transaction costs}

The variables in factor 1 , which explain 23.9 per cent of the variance, refer mainly XP lower transportation costs, lower costs of establishing projects, avail surplus labour benefit, low labour costs and overcome tariff and non-tariff barriers. This factor has high positive loadings with variables motivating the firms to lower their transaction costs. It is therefore, labelled as "lowering the transaction costs". 
Table-6: Exploratory factor analysis on the motives for FDI in Pakistan

\begin{tabular}{|c|c|c|c|c|}
\hline Factors and Variables & $\begin{array}{l}\text { Factor-item } \\
\text { Correlation }\end{array}$ & Eigenvalue & Variance & $\begin{array}{c}\text { Cumulative } \\
\text { Variance }\end{array}$ \\
\hline \multicolumn{5}{|l|}{ Factor I: } \\
\hline Lowering the transaction costs & & 5.25302 & $23.9 \%$ & $23.9 \%$ \\
\hline Low transport costs & .90032 & & & \\
\hline Lower costs of establishing projects & .86147 & & & \\
\hline To overcome non-tariff barriers & .79796 & & & \\
\hline Surplus labour & .78693 & & & \\
\hline Low labour costs & .72107 & & & \\
\hline To overcome tariff barriers & .65044 & & & \\
\hline \multicolumn{5}{|l|}{ Factor II: } \\
\hline Psychic distance & & 2.75949 & $12.5 \%$ & $36.4 \%$ \\
\hline Cultural links & .95948 & & & \\
\hline Geographical proximity & .95182 & & & \\
\hline \multicolumn{5}{|l|}{ Factor III: } \\
\hline Input prices & & 2.22886 & $10.1 \%$ & $46.6 \%$ \\
\hline Availability of raw materials & .94820 & & & \\
\hline Low production costs & .55877 & & & \\
\hline \multicolumn{5}{|l|}{ Factor IV: } \\
\hline Special privileges & & 1.90572 & $8.7 \%$ & $55.2 \%$ \\
\hline Market growth prospects & -.62816 & & & \\
\hline Special privileges by the Govt. & .93337 & & & \\
\hline \multicolumn{5}{|l|}{ Factor V: } \\
\hline$\overline{\text { Special economic zones }}$ & & 1.55536 & $7.1 \%$ & $62.3 \%$ \\
\hline Special economic zones & .82876 & & & \\
\hline Historical links & -.58808 & & & \\
\hline \multicolumn{5}{|l|}{ Factor VI: } \\
\hline$\overline{\text { Expansion }}$ of business & & 1.37737 & $6.3 \%$ & $68.5 \%$ \\
\hline Protection of existing export market & .89313 & & & \\
\hline Access to neighbouring markets & .71640 & & & \\
\hline \multicolumn{5}{|l|}{ Factor VII: } \\
\hline$\overline{\text { Strategic reasons }}$ & & 1.24877 & $5.7 \%$ & $74.2 \%$ \\
\hline Parent's strategy & .75737 & & & \\
\hline Competitor's reaction & .56361 & & & \\
\hline Product diversification & .46124 & & & \\
\hline \multicolumn{5}{|l|}{ Factor VIII: } \\
\hline Higher profits & & 1.08332 & $4.9 \%$ & $79.1 \%$ \\
\hline Higher rates of profits & .77796 & & & \\
\hline Lack of competition & .76940 & & & \\
\hline \multicolumn{5}{|l|}{ Factor IX: } \\
\hline Market size & & 1.01012 & $4.6 \%$ & $83.7 \%$ \\
\hline Market size & .92235 & & & \\
\hline
\end{tabular}

\section{Psychic distance}

Factor 2 comprises two variables, cultural links and geographical proximity with the highest positive loadings and explaining 12.5 per cent of the variance. This refers to the factors that motivate MNEs to invest in 
100 The Lahore Journal of Economics, Vol.5, No.2

Pakistan on account of cultural and geographic proximity. It is therefore, listed as the "psychic distance" factor.

\section{Input prices}

Factor 3 indicates that the availability of raw materials for production and low production costs is another group of variables motivating these MNEs to invest in Pakistan on account of costeffectiveness. This group of variables tends to explain about 10 per cent of the variance with high positive factor-item correlation and is identified as the "input prices".

\section{Special privileges}

This factor appeared with a high positive correlation of 0.93337 with the variable "special privileges by the government". Factor-item loading on the market growth prospects variable appeared to be negative. This factor indicates that FDI in Pakistan is motivated by the special privileges of the government and not by the market growth prospects and is therefore, designated as "special privileges". It explains 8.7 per cent of the variance.

\section{Special economic zones}

High and positive factor-item loading is shown by special economic zones variable, while a negative and relatively lower factor-item correlation exists between factor 5 and historical links variable. This shows that special economic zones in Pakistan motivate MNEs to invest and not the historical links. The factor explains 7 per cent of the variance and is branded as "special economic zones".

\section{Expansion of business}

There were two variables in this group; protection of existing export market and access to neighbouring markets both with a high positive correlation with factor 6 . This factor suggests the fact that localisation of production or sales by MNEs in the sample are motivated by their desire to maintain and expand their business volume. This group explains 6.3 per cent of the variance and is categorised as "expansion of business".

\section{Strategic reasons}

This group comprises variables like parent's strategy, competitor's reaction and product diversification, which are largely related to the 
business strategy of MNEs. This factor explains 5.7 per cent of the variance and is termed as "strategic reasons".

\section{Higher profits}

The two variables, higher rates of profits and lack of competition, constitute this factor with positive high factor-item loadings. Lack of competition in a market strengthens the position of a firm towards earning more profits. The factor explains about 5 per cent of the variance and is classified as "higher profits".

\section{Market size}

Among the nine factors produced by the factor analysis, market size appeared as a unique factor with a very high positive factor loading of 0.92235 and explaining 4.6 per cent of the variance. This factor suggests the fact that market size in Pakistan persuades the MNEs to invest there. Hence, this factor is termed as the "market size".

A detailed analysis of the factors, variables in the factors and factor-variable correlations, based on internal reliability analysis and alpha coefficients, was performed. Factors with low Cronbach's alpha values, inconsistent meanings, and variables with low internal reliability were excluded from the analysis ${ }^{7}$. The remaining variables were again factor analysed. This process of factor purification produced four factors, explaining 79 per cent of the overall variance, with items loading on appropriate factor and also consistent with economic theory (Table-7).

\footnotetext{
${ }^{7}$ Variables excluded from their respective factors were market growth prospects, historical links, lack of competition, higher rates of profits, special economic zones, product diversification, parent's strategy, competitors' reaction, and special privileges by the government.
} 
102 The Lahore Journal of Economics, Vol.5, No.2

Table-7: Purified factor analysis on the motives for FDI in Pakistan

\begin{tabular}{|c|c|c|c|c|c|}
\hline Factors and Variables & $\begin{array}{c}\text { Factor-item } \\
\text { Correlation } \\
\end{array}$ & Alpha & Eigenvalue & Variance & $\begin{array}{c}\text { Cumulative } \\
\text { Variance }\end{array}$ \\
\hline \multicolumn{6}{|l|}{ Factor I: } \\
\hline $\begin{array}{l}\text { Lowering the transaction } \\
\text { costs }\end{array}$ & & 0.88 & 4.65098 & $39 \%$ & $39 \%$ \\
\hline Low transport costs & 0.87186 & & & & \\
\hline Surplus labour & 0.86483 & & & & \\
\hline $\begin{array}{l}\text { To overcome non-tariff } \\
\text { barriers }\end{array}$ & 0.86433 & & & & \\
\hline $\begin{array}{l}\text { Lower costs of } \\
\text { establishing projects }\end{array}$ & 0.80932 & & & & \\
\hline $\begin{array}{l}\text { To overcome tariff } \\
\text { barriers }\end{array}$ & 0.72229 & & & & \\
\hline \multicolumn{6}{|l|}{ Factor II: } \\
\hline Psychic distance & & 0.99 & 1.97280 & $16 \%$ & $55 \%$ \\
\hline Geographical proximity & 0.98730 & & & & \\
\hline Cultural links & 0.98724 & & & & \\
\hline \multicolumn{6}{|l|}{ Factor III: } \\
\hline Input prices & & 0.74 & 1.62124 & $13 \%$ & $68 \%$ \\
\hline $\begin{array}{l}\text { Availability of raw } \\
\text { materials }\end{array}$ & 0.84960 & & & & \\
\hline Low production costs & 0.79982 & & & & \\
\hline Low labour costs & 0.61336 & & & & \\
\hline \multicolumn{6}{|l|}{ Factor IV: } \\
\hline Expansion of business & & 0.59 & 1.25813 & $11 \%$ & $79 \%$ \\
\hline $\begin{array}{l}\text { Protection of existing } \\
\text { export market }\end{array}$ & 0.85287 & & & & \\
\hline $\begin{array}{l}\text { Access to neighbouring } \\
\text { markets }\end{array}$ & 0.81139 & & & & \\
\hline \multicolumn{6}{|l|}{ Factor V: } \\
\hline Market size & & n.a. & & & \\
\hline Market size & 1.00 & & & & \\
\hline
\end{tabular}

Notes: 1- n.a. denotes not applicable.

As it is not possible to test the internal reliability of a factor containing a single variable e. g. market size, no alpha coefficient is produced for this factor. The factor is presented in Table-7 as the fifth factor with a factor-item correlation of 1.00 . The estimates of the factor- 
item loadings, reliability of factors (alpha values) and the variance explained by them indicate the appropriateness of results. This is also supported by the fact that although 10 out of the 22 variables are excluded from the analysis, only 5 per cent of the variance is lost. This indicates that variables included in the analysis contain most of the variance. Table-7 presents the factors finally extracted through purified factor analysis.

Simple averages indicate the market size and growth variables as the most cited reasons for FDI in Pakistan by MNEs in the sample. The use of EFA also reveals that the MNEs investing in Pakistan are motivated by market size, above all. The other important factors in order of their average importance ${ }^{8}$ are expansion of business; low input prices; desire to lower the transaction costs and psychic distance. The "expansion of business" factor signifies the growth motive of the MNEs and the "low input prices" factor alludes to the comparative cost advantage in Pakistan.

\section{Conclusion}

Although market size and growth appear to be the most important motives for FDI in Pakistan, there seems to be a variety of other factors motivating each of the firms to invest in Pakistan. Results of the factor analysis exhibit the fact that expansion of business; low input prices; desire to lower the transaction costs and psychic distance factor are the likely explanations for FDI in Pakistan.

The study appraises the opinions and perceptions of the managers of MNEs in Pakistan about various aspects of FDI over there. On the whole, it emerges from the survey that there is a potential in the economy to absorb larger amounts of FDI inflows. However, to attract and entertain such inflows more appropriately, some bold reforms are needed which can help in building a better image of the economy. It can be argued that satisfaction on the part of existing MNEs in Pakistan seems to be an important determinant of FDI. There stands a need for greater efforts by the government to support and sustain the existing investments and with the prospects of more to come as well.

\footnotetext{
${ }^{8}$ The average importance of factors is calculated by taking the average of the sample means presented in Table- 3 of the variables in each factor.
} 
104 The Lahore Journal of Economics, Vol.5, No.2

\section{References}

Ajami, R. A. \& Ricks D. A., 1981 Motives of Non-American Firms Investing in the United States. Journal of International Business Studies, 7: 25-34.

Artisien P., Rojec M. \& Svetlicic M., 1991 Yugoslav Foreign Direct Investment in Less Developed Countries. In P. J. Buckley \& J. Clegg (eds.), Multinational Enterprises in Less Developed Countries. Basingstock and London: Macmillan.

Brash O. T., 1966 American Investment in Australian Industry. Canberra: Australian University Press.

Bryman A. \& Cramer D., 1997 Quantitative Data Analysis with SPSS for Windows, London: Routledge.

Buckley P. J. \& Clegg J., 1991 Multinational Enterprises in Less Developed Countries. Basingstock and London: Macmillan.

Buckley P. J. \& Mathew A. M., 1979 The Motivation for Recent First Time Direct Investments in Australia by UK firms. Management International Review, 19: 57-70.

Buckley P. J. \& Casson M. R., 1976 The Future of the Multinational Enterprise. London: Macmillan.

Buckley, P. J., 1992 Studies in International Business. Houndmills: St. Martin's Press.

Buckley, P. J., Newbould, G. D. \& Thurwell, J. C., 1988 Foreign Direct Investment by Smaller UK Firms: The Success and Failure of FirstTime Investors Abroad. London: Macmillan.

Bürgenmeier B., 1991 Swiss Foreign Direct Investment. In B. Bürgenmeier \& J. L. Mucchielli (eds.) Multinational and Europe 1992: Strategies for the Future. London: Routledge.

Cavusgil S. T. \& Zou S., 1994 Marketing Strategy-Performance Relationship: An Investigation of the Empirical Link in Export Market Ventures, Journal of Marketing, 58: 1- 21.

Chen E. K. Y., 1983 Multinationals from Hong Kong. In S. Lall (ed.) The New Multinationals: The Spread of Third World Enterprises, Chichester: John Wiley and Sons. 
Deshpande R., 1982 The Organisational Context of Market Research Uses, Journal of Marketing, 46: 91-101.

Dun \& Bradstreet, 1996 Who Owns Whom 1995-96. London: Dun \& Bradstreet.

Dunning J. H., 1986 Japanese Participation in British Industry. London: Croom Helm.

Dunning J. H. \& Norman G., 1987 The Location Choice of Offices of International Companies. Environment and Planning A, 19: 613631.

Dunning J. H., 1973 The Determinants of International Production. Oxford Economic Papers, 25 (3): 289-336.

Enderwick P., 1989 Some Economics of Service-Sector Multinational Enterprises. In P. Enderwick (ed.) Multinational Service Firms. Routledge: London.

Franko L. G., 1976 The European Multinationals: A Renewed Challenge to American and British Big Business. New York: Harper and Row.

Glaister K. W. \& Buckley P. J., 1994 UK International Joint Ventures: An Analysis of Patterns of Activity and Distribution, British Journal of Management, 5: 33-51.

Glaister K. W. \& Buckley P. J., 1996 Strategic Motives for International Alliance Formation, Journal of Management Studies, 33 (3): 301332.

Globerman S., 1994 Canadian-Based Multinationals, Albertia: The University of Calgary Press.

GOP (Government of Pakistan) 1993 Pakistan Investment Guide 1992-93. Islamabad: Ministry of Industries.

Grube1, H. G., 1987 Multinational Banking. In P. Enderwick (ed.) Multinational Service Firms. Routledge: London.

Hair J. F. (Jr.), Anderson R. E., Tatham R. L. \& Black W. C. 1995 Multivariate Data Analysis, Englewood Cliffs: Prentice Hall.

Hedderson J., 1991 SPSS/PC + Made Simple, California: Wadsworth. 
106 The Lahore Journal of Economics, Vol.5, No.2

Hood N. \& Taggart J. H., 1997 German Foreign Direct Investment in the UK and Ireland: Survey Evidence, Regional Studies, 31 (2): 139-150.

Kline, P., 1994 An Easy Guide to Factor Analysis. Routledge: London.

Kumar K. \& Kim K. Y., 1984 The Korean Manufacturing Multinationals. Journal of International Business Studies, 15: 45-61.

Kumar, N., 1994 Determinants of Export Orientation of Foreign Production by U.S. Multinationals: An Inter-Country Analysis, Journal of International Business Studies, 25 (1): 141-156.

Lecraw D., 1977 Direct Investment by Firms from Less Developed Countries. Oxford Economic Papers, 29, (3): 442-57.

Nicholas S. J., 1982 British Multinational Investment before 1939. Journal of European Economic History, 11: 605-630.

Reuber, G. L., Crokelle1, H., Emerson, M. \& Gallias-Hamono, G., 1973 Private Foreign Investment in Development. London: Clarendon Press.

Shepherd D., Silberston A. \& Strange R., 1985 British Manufacturing Investment Overseas. London and New York: Methuen.

Stopford J. M., 1974 The Origins of British-based Multinational Manufacturing Enterprises. Business History Review, 48: 303-335.

Tu J-H. \& Schive C., 1995 Determinants of Foreign Direct Investment in Taiwan Province of China: A new approach and findings. Transnational Corporations, 4: 93-103.

Wilkins M., 1970 The Emergence of Multinational Enterprise: American Business Abroad from the Colonial Era to 1914. Cambridge, M A: Harvard University Press.

Wilkins M., 1974 The Maturing of Multinational Enterprise: American Business Abroad from 1914 to 1970. Cambridge, M A: Harvard University Press.

World Bank, 1989 Foreign Direct Investment from the Newly Industrialized Economies. Industry and Energy Department Working Paper, Industry Series Paper No. 22. World Bank. 